\title{
Secondary Ion Mass Spectrometry : Theory and Recent trends
}

\author{
Mirang Byeon, Da Young Kim, Tae Eun Hong
}

Korea Basic Science Institute

\section{이차이온질량분석기의 원리와 분석법 동향}

\author{
변미랑, 김다영, 홍태은 \\ 한국기초과학지원연구원
}

(Received December 10, 2019 ; Accepted December 16, 2019)

\begin{abstract}
s
Secondary lon Mass Spectrometry(SIMS) is an analytical method that measures the distribution and concentration of elements or compounds by analyzing the mass of secondary ions released by irradiating ion beams with energy of hundreds $\mathrm{eV}$ to $20 \mathrm{keV}$ on the sample surface. Unlike other similar analytical instruments, SIMS directly detect the elemental ions that constitute a sample, allowing you to accurately identify components and obtain concentration information in the depth direction. It is also a great feature for measuring isotopes and analyzing light elements, especially hydrogen. In particular, with the development of materials science, there is an increasing demand for trace concentration analysis and isotope measurements in the micro-regions of various materials. SIMS has a short history compared to other similar methods; nevertheless, SIMS is still advancing in hardware and is expected to contribute to the development of materials science through research and development of advanced analytical techniques.
\end{abstract}

Key words : Secondary Ion Mass Spectrometry, Analytical method, Ion Microprobe

\section{1. 서론}

우리나라에 반도체 산업이 뿌리를 내리기 시작한 1980 년대 초반부터 표면분석기기에 대한 수요가 급증하였고, 반도체 기업을 중심으로 다양한 표면분석기기를 구축하
기 시작했다. 현재 국내에 구축 및 운영 중인 X-선 광전 자 분광기(X-ray Photoelectron Spectroscopy, XPS)와 이차이온질량분석기(Secondary Ion Mass Spectrometry, $\mathrm{SIMS}$ ) 등은 시료 표면의 구성 성분 및 농도 분포를 1차원, 2차원, 3 차원으로 파악할 수 있는 대표적인 표면분석기기 


\section{특 집 부면랑, 김다영, 홍태은}

이다. 표면분석기기는 에너지를 가진 일차입자를 시료에 주사하여 수 $u m-n m$ 깊이 이내의 표면에서만 방출되는 이차입자의 특성 에너지 또는 질량 등을 분류한다.

이차이온질량분석기는 높은 에너지의 이온(일차이온, primary ion)을 고체시료 표면에 충돌시켰을 때 스퍼터 링(sputtering) 현상에 의해 방출되는 이온(이차이온, secondary ion)을 질량분석기를 통해서 분별하여 시료 의 구성 원소, 화합물의 종류 및 농도를 분석하는 기기이 다. 이차이온질량분석기의 일차이온빔 크기를 수 $\mu \mathrm{m}$ 에 서 수십 $\mathrm{nm}$ 까지 줄일 수 있어 이온 탐침 질량 분석기(ion microprobe mass spectrometry)라 하며, 반도체와 같 은 미세구조를 가진 표면에서 미량원소 분석이 가능하다.

이차이온질량분석기는 1960 년대 초, 프랑스에서 개발 을 시작하여 재료과학의 발전과 함께 각종 재료의 미소영 역에서 극미량 농도 분석 및 동위원소를 측정하기 위해 1970년까지 미국, 프랑스 및 일본에서 이를 상용화하였 다. 현재 보급된 이차이온질량분석기의 대부분은 시료의 표면 및 내부의 미량성분 분석이 필요한 반도체, 철강, 바 이오, 지구과학 등과 같은 분야에서 운용하고 있다. 세라 믹 분야에는 소재 표면에서 원소별 이미지 분포 분석, 주 성분 및 미량원소의 깊이방향 분포 분석, 동위원소비 분 석 등을 통해 세라믹을 구성하는 물질의 정성, 정량 정보 를 연구하는 위주로 활용하고 있다.

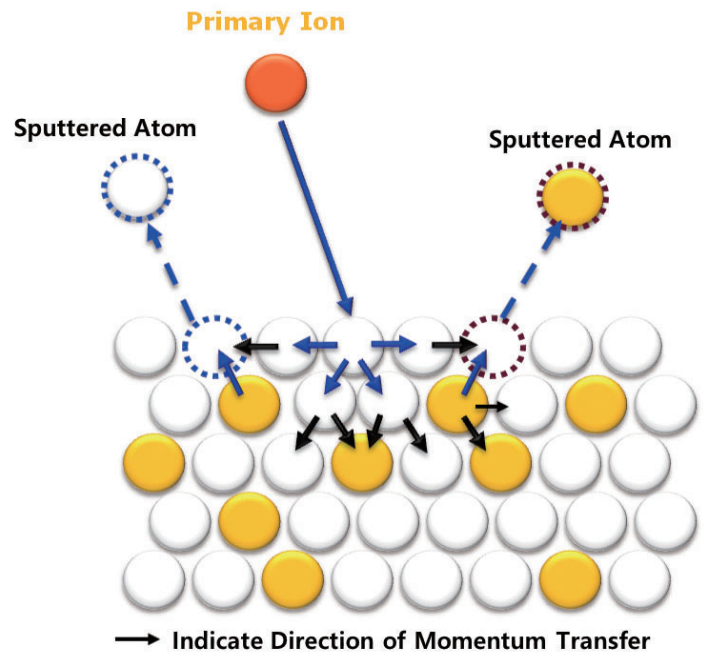

그림 1. 연쇄충돌 현상
본 원고에서 이차이온질량분석기의 기본원리와 구성 및 특징에 대한 설명과 다양한 분야에서 이차이온질량분 석기를 활용한 연구 결과를 고찰하고 분석 동향에 대해 소개하고자 한다.

\section{2. 본론}

\section{2-1. 이차이온질량분석기의 원리}

\section{2-1-1. 스퍼터링[1-5]}

에너지를 가진 일차이온을 시료에 주입하면 그림 1과 같이 일차이온은 시료 내로 들어가 시료 원자와 연쇄 충 돌(collision cascade)이 일어나며, 주변의 시료 원자에 운동에너지를 전달한다. 전달된 운동에너지가 결정격자 의 전위 장벽을 넘을 경우 시료원자가 격자점으로부터 떨 어지는 연쇄반응(knock-on effect)이 일어난다. 연쇄반 응에 의해 변위를 받은 원자 중 표면 근처의 원자는 외부 로 방출되고, 이로 인해 시료는 식각(etching)이 일어난 다. 그림 2 와 같이 시료를 구성하는 원자의 중성입자, 양 이온, 음이온, 전자가 방출되는 현상을 스퍼터링이라 한 다. 스퍼터링 효율은 수 eV에서 $10-30 \mathrm{keV}$ 범위까지는 일차이온 에너지에 따라 거의 비례하여 증가한다. 또한 스퍼터링 효율은 입사각에 따라 $1 / \cos \theta$ 함수로 변하는 경

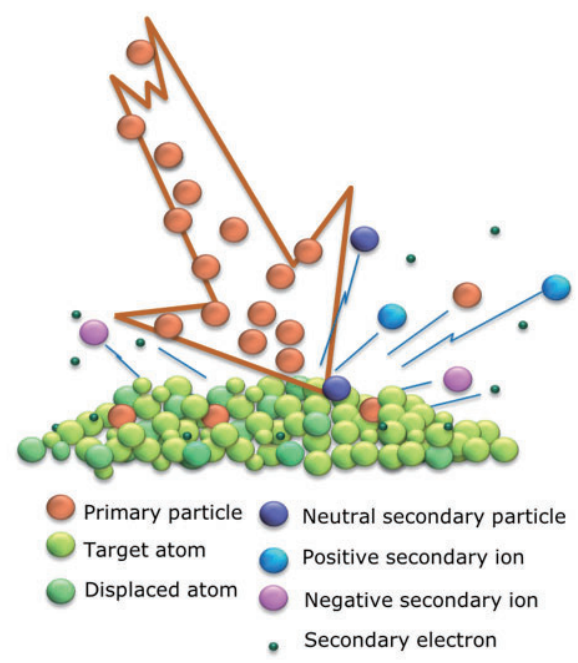

그림 2. 일차이온빔의 충돌에 따른 스퍼터링 현상 


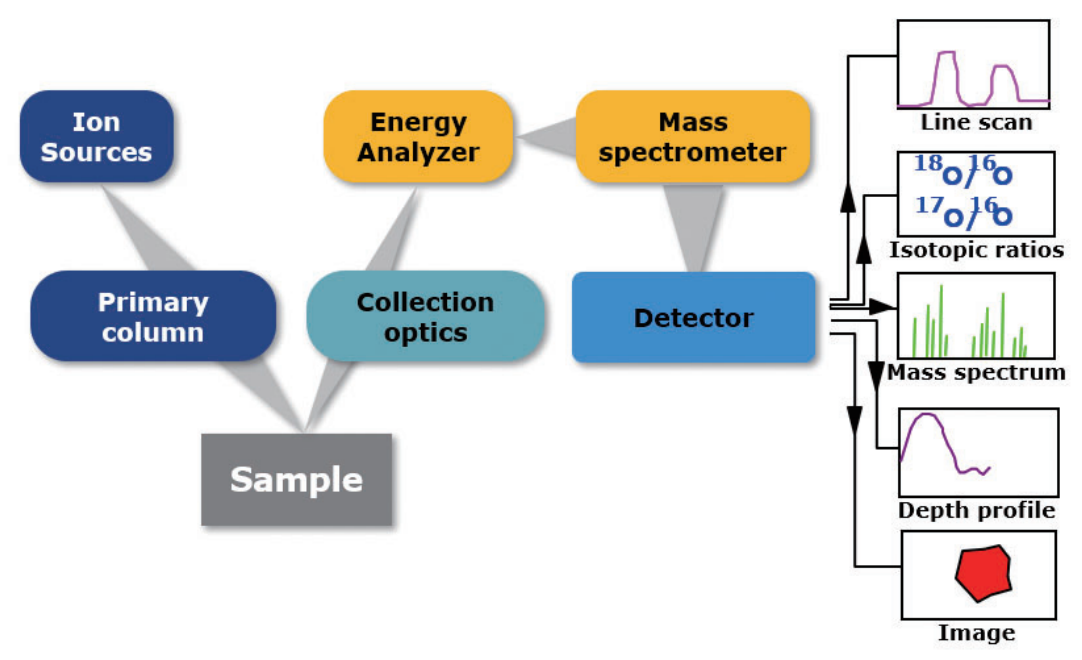

그림 3. 이차이온질량분석기의 구조

향이 나타난다.

\section{2-1-2. 이차이온화 ${ }^{[6-8]}$}

정량분석에서 가장 중요한 물리량은 시료에서 방출된 입자의 이차이온화 효율이다. 이차이온화 효율은 일차이 온 주입에 의해 방출된 특정원소의 이차이온 수를 스퍼터 링된 동종의 모든 원자(이온도 포함) 수로 나눈 값으로 정 의한다. 물질에 따른 이차이온화 효율을 알면 이차이온질 량분석기를 활용하여 정량 분석이 가능하다. 하지만 이차 이온화 효율은 시료를 구성하는 물질에 따라 크게 변하는 매트릭스 효과(matrix effect)때문에, 표준시편이 없으 면 정량 분석을 할 수 없다.

\section{2-2. 이차이온질량분석기의 구성}

이차이온질량분석기는 그림 3과 같이 일차이온을 생성하 고, 일차이온을 시료까지 운반하는 일차이온컬럼(primary ion column), 시료에서 튀어나온 이차이온을 추출하여 에너 지차와 질량차 등에 의해 분류하는 질량분석계(mass spectrometer), 분류된 이차이온의 양을 측정하는 데이터 처 리 시스템(detector system), 진공 시스템(vacuum system) 으로 구성된다.

\section{2-2-1. 일차이온컬럼[9-12]}

이차이온질량분석기는 일차이온을 생성하기 위해 주 로 가스 성분이온(예: $\left.\mathrm{O}_{2}^{+}, \mathrm{Ar}^{+}\right)$을 인출하는 듀오플라즈 마트론(duoplasmatron)과 표면이온화 현상을 이용한 $\mathrm{Cs}^{+}$이온소스 두 종류를 주로 사용하며, 그 개략도는 그 림 4 와 같다.

이러한 일차이온은 주로 수백 $\mathrm{eV}$ 에서 수십 $\mathrm{keV}$ 의 에 너지를 가지며, 스퍼터링 효율을 고려하여 다양한 충돌각 도(collision angle)로 시료에 주입한다. 일차이온은 시 료 내 어떤 원소의 정보를 얻고자 하는가에 따라 선택한 다. 동일한 원소를 검출하더라도 어떤 일차이온을 시료에 주입하는 가에 따라 이차이온의 검출감도가 달라진다. 그 림 5 는 이차이온의 검출 감도를 높이기 위해 사용하는 일 차이온의 종류를 나타내는 표이다.

검출하려는 이차이온의 이온화 효율을 높일 수 있도록 일차이온의 종류, 에너지, 충돌 각도를 설정해야 한다. 대 부분의 이차이온질량분석기는 두 종류의 일차이온 발생 장치를 모두 갖추고 분석 목적에 적합한 일차이온을 선택 하여 사용한다. 일반적으로 주기율표 오른쪽에 위치하여 전자 친화력이 높은 원소를 검출할 때는 음이온을 잘 생 성시키는 세슘 이온 $\left.{ }^{(133} \mathrm{Cs}^{+}\right)$을 사용하고, 주로 주기율표 왼편에 위치하여 이온화 전위가 낮은 원소를 검출할 때는 양이온을 잘 생성시키는 산소 이온 $\left(\mathrm{O}_{2}{ }^{+}, \mathrm{O}^{-}\right)$을 사용한다. 불활성 원소 $(\mathrm{He}, \mathrm{Ar}, \mathrm{Kr}$ 등)를 검출하거나 매질효과 


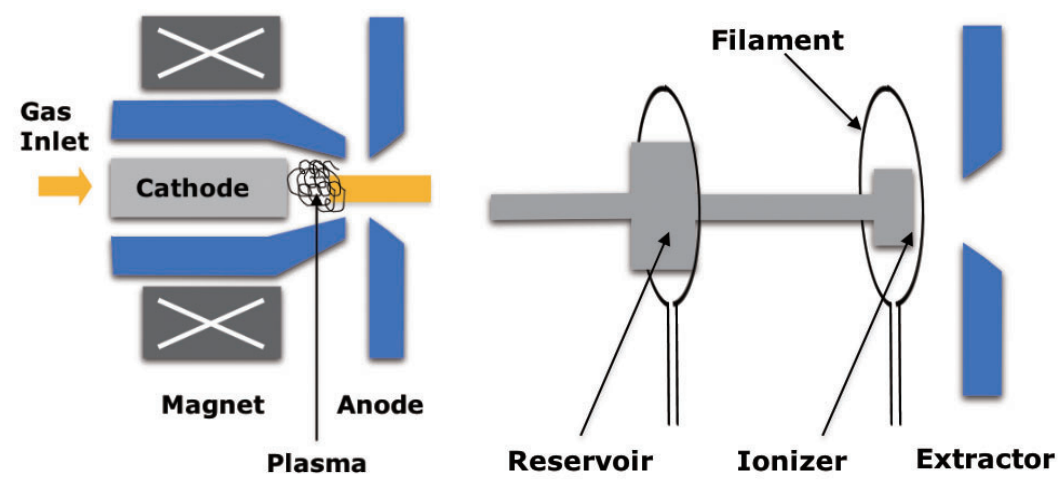

그림 4. (a)듀오플라즈마트론(duoplasmatron) 이온원, (b)표면이온화 일차이온발생장치

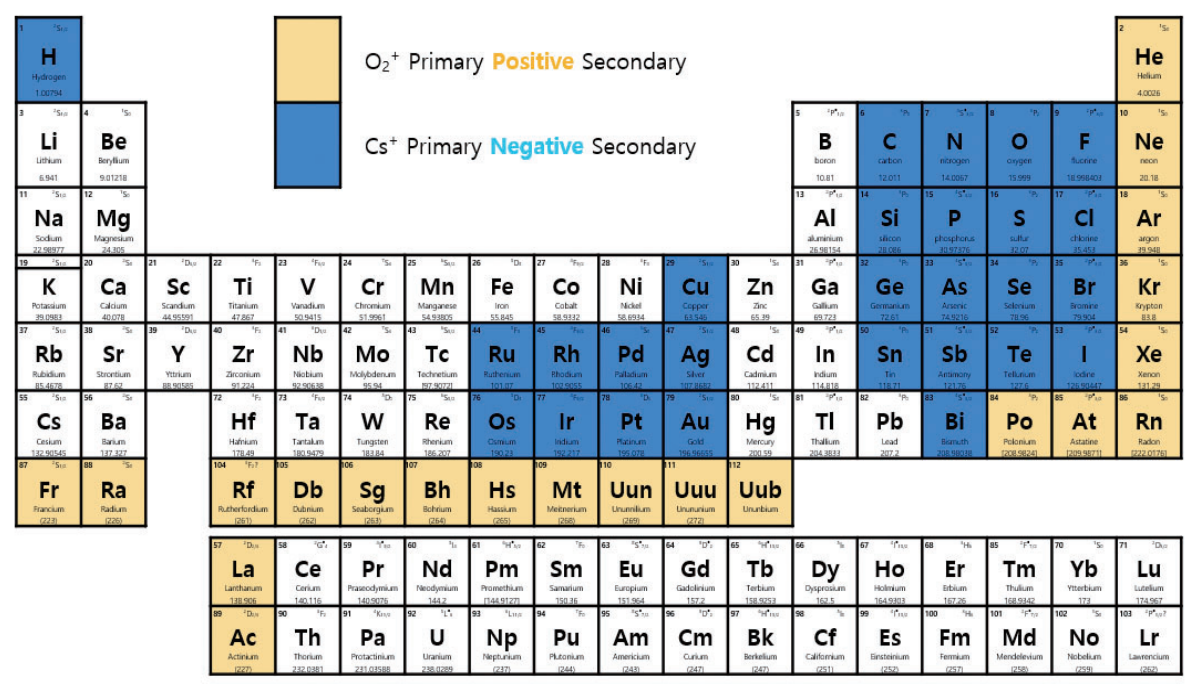

그림 5. 주기율표상 원소에 따른 최적 일차이온의 선택

(matrix effect)를 줄이기 위해 일차이온으로 세슘이온 $\left(\mathrm{Cs}^{+}\right)$을 사용하고, 이차이온으로 $\mathrm{MCs}^{+}$(예: $\mathrm{ArCs}^{+}$, $\mathrm{InCs}{ }^{+}$)와 같은 분자이온을 검출한다. 일차이온컬럼은 일 차이온을 안정적으로 시료로 운반하기 위해 초고진공도 상태를 항상 유지하고 있다.

\section{2-2-2. 질량분석계 ${ }^{[13-15]}$}

질량분석계(mass spectrometer)는 이중집속형 질량 분석계(double focusing mass spectrometer), 사중극 형 질량분석계(quadrupole mass spectrometer), 비행
시간형 질량분석계(time of flight mass spectrometer) 3 종류로 나눠 사용하고 있다.

그림 6의 이중집속형 질량분석계(double focusing mass spectrometer)는 자기장과 전기장을 유기적으로 결합한 장치로 동일 질량을 가진 이차이온을 같은 초첨면 에 집속하도록 질량 분해능을 향상시킨 장치이다. 이차이 온 에너지를 일정하게 유지할 경우 질량분산(입사이온의 궤도반경에 의존)은 자기장 강도에 반비례한다. 즉, 전기 장을 일정하게 유지하면서 자기장을 서서히 강하게 하면 질량수가 작은 이차이온에서 큰 이차이온까지 모두 순차 


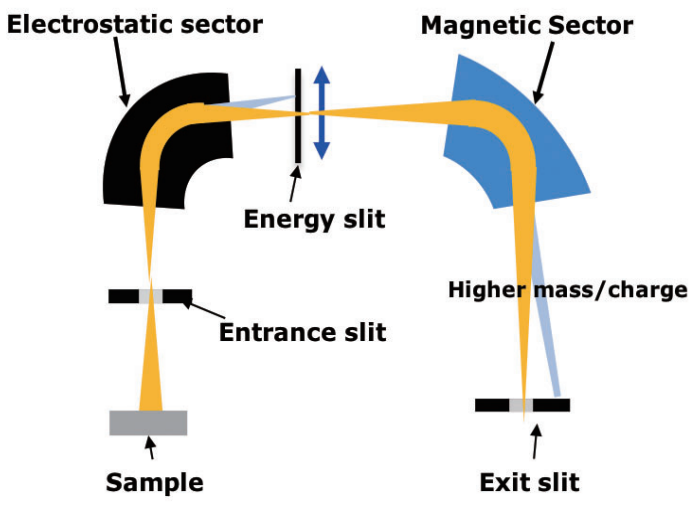

그림 6. 이중접속방식을 택한 자기섹터형 질량분석계

적으로 질량분리 슬릿을 통과하여 질량 스펙트럼을 얻을 수 있다.

질량필터의 능력은 질량분해능(mass resolution)으로 정의한다. 질량분해능이란 질량스펙트럼(mass spectrum) 에서 서로 인접한 두 개의 질량 피크(mass peak)를 분리구분해 내는 능력이다. 질량분해능은 측정하고자 하는 질 량 $(\mathrm{M})$ 을 분리하고자 하는 질량간 거리 $(\triangle \mathrm{M})$ 로 나눈 값으로 정의한다.

$$
\text { mass resolution }=\frac{M}{\Delta M}
$$

동일한 장비로 높은 질량분해능을 얻기 위해서는 질량 신호의 일부를 잘라내야 하는 경우가 자주 발생한다.

그림 7의 사중극형 질량분석계(quadrupole mass spectrometer)는 4개의 평행한 금속 막대에 극성이 다른 직류전압과 고주파전압이 합쳐진 전압을 인가한다. 사극 자의 한쪽 끝에 입사된 이차이온은 입사축과 수직방향인 고주파전기장에 의해서 상하로 진동하면서 이동한다. 특 정 진동 조건을 만족하는 특정질량의 이온이 안정적인 진 동을 하여 반대쪽 끝의 질량분해 슬릿을 지나 검출기에 도달한다. 질량수가 다른 이온은 발산하여 주변의 전극자 에 흡수되거나 질량분리 슬릿을 통과할 수 없게 된다. 이 렇게 하면, 가벼운 원소부터 무거운 원소까지 질량스펙트 럼을 얻을 수 있다.

사중극형 질량분석계는 소형 경량으로 고속 질량 스캔
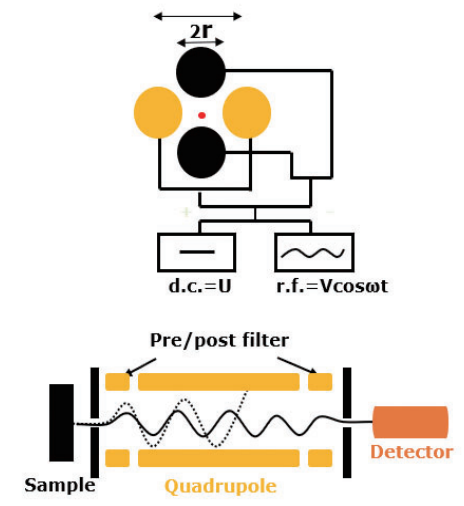

그림 7. 사중극형 질량분석계

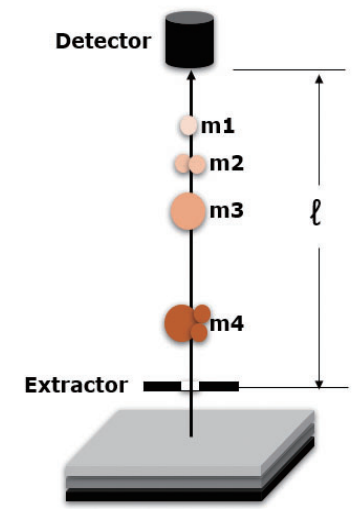

그림 8. 비행시간형 질량분석계

이 가능하다. 이중집속형 질량분석계에 비해 이차이온 가 속전압을 수백 V이하로 낮게 설정할 수 있는 장점이 있 다. 또한 복잡한 이차이온 광학계가 필요하지 않아 작업 이 용이하다. 질량분해능은 300 1000이 실용한계다.

그림 8의 비행시간형 질량분석계(time of flight mass spectrometer)는 일차이온빔을 펄스(pulse) (수십 $\mathrm{ns} \sim \mathrm{ns})$ 형태로 시료에 조사한다. 시료 표면에서 거의 동 시에 발생하는 이차이온군(질량수 $\mathrm{M}, \mathrm{M} 1<\mathrm{M} 2<\mathrm{M} 3, \ldots$ )을 일정한 가속전압으로 가속한다. 가속된 이차이온군 중 가 벼운 질량은 검출기에 먼저 도달하고, 무거운 질량은 나 중에 도달한다. 즉 질량에 따라 비행 시간이 다르므로 가 벼운 질량에서 무거운 질량 순(M1, M2, M3,...)으로 질 량스펙트럼이 나타난다. 그러므로 적은 시료의 양으로 다 원소 검출이 가능한 장점이 있다. 질량분해능은 일차이온 
의 펄스 폭과 이차이온의 주행거리에 좌우되며 10,000 이상의 질량분해능도 쉽게 얻을 수 있다.

\section{2-2-3. 데이터 처리 시스템 ${ }^{[16]}$}

이차이온질량분석기의 검출기는 본질적인 간섭으로 인 한 노이즈는 존재하지 않고, 원리적으로 미소신호 검출이 가능하기 때문에 극미량 분석이 가능하다. 이차이온질량분 석기의 데이터 처리 시스템은 그림 9와 같이 주로 $1 \mathrm{Mcps}$ 이하의 신호에 적합한 전자증배관(electron multiplier)을 사용한다. 이차이온이 다이노드에 충돌하면 이차전자가 발 생한다. 발생한 이차전자는 연속적으로 배열된 다이노드와 충돌하여 전기 신호가 증폭한다. 전자증배관은 시간에 따 라 고유의 노이즈가 증가하여 검출한계가 저하되고 그 결 과 데이터의 재현성과 정량 정밀도가 떨어지는 문제점을 가지고 있다.

\section{2-3. 이차이온질량분석기의 특징과 장단점 ${ }^{[17-18]}$}

이차이온질량분석기의 장점은 첫째, 주기율표상의 거 의 모든 원소를 검출할 수 있다. X선 광전자 분광법, 오 제이 전자 분광법 (Auger Electron Spectroscopy, $\mathrm{AES}$ )과 달리 수소, 헬륨, 리튬 등 경원소를 포함하여 중 원소 측정이 가능하다.

둘째, 검출한계(detection limit)가 낮아 $\mathrm{ppm}-\mathrm{ppb}$ 수 준의 낮은 농도까지 분석할 수 있다. 시료의 구성 성분, 이온화 효율 등, 분석 조건에 따라 원소별 검출 한계는 조 금씩 달라질 수 있다.

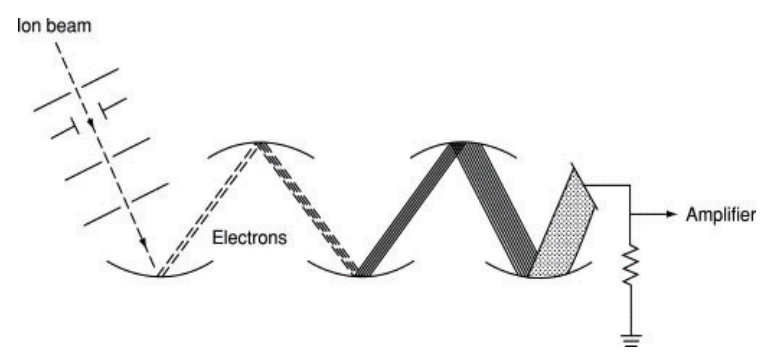

그림 9. 불연속 다이노드 전자증배관의 모식도 (McFadden WH (1973) Techniques of Combined Gas Chromatography/ Mass Spectrometry. Chichester, UK: Wiley-Interscience with permission)
셋째, 시료 표면에 충돌하는 일차이온의 직경을 수 $\mathrm{nm}-\mu \mathrm{m}$ 까지 줄일 수 있어 초미세 영역 내 분석이 가능 하다. 시료 내 특정 위치에서 분석을 할 수 있어 시료 조 직 분석 자료와 연계하여 해석할 수 있다. 수평분해능 (spatial resolution)을 포함하여 수직분해능(depth resolution), 질량분해능(mass resolution), 에너지분해 능(energy resolution) 또한 뛰어나다.

마지막으로 다른 질량분석기와 달리 화학적 전처리를 하지 않아 화학적 전처리 과정에서 생기는 다양한 변수를 제거할 수 있다. 시료 준비 과정이 비교적 단순하여 시료 표면 상태를 그대로 분석할 수 있다.

이차이온질량분석기의 단점은 첫째, 시료의 표면을 파 괴하는 표면분석방법이다. 분석 이후 시료 표면이 최소 수 $n m$ 에서 수 um 깊이까지 깎여 사라진다.

둘째, 표준 시료가 없을 경우 정량분석이 어렵다. 분석 조건과 모재의 성분에 따라 이차이온의 이온화율이 달라 져 검출 신호의 크기가 변화한다. 따라서 검출한 신호를 조성비로 변환하기 위해서는 시료와 화학조성 및 구조가 일치하는 표준시료를 동일한 조건으로 분석해야 정량화 가 가능하다.

마지막으로 부도체 시료를 분석할 경우 표면 대전 현상 이 일어나 분석 결과가 왜곡될 수 있다. 시료에서 이차이 온이 방출함에 따라 시료 표면에 전하가 쌓이는 현상이 발생한다. 시료의 표면이 음전하 또는 양전하로 대전될 경우 일차이온의 입사 경로와 이차이온의 방출 경로에 간 섭 또는 차단이 일어나 분석 결과가 왜곡되는 경우가 발 생한다. 이러한 문제를 해결하고자 시료 표면을 나노미터 두께의 전도체 박막(탄소, 백금, 금 등)으로 얇게 코팅하 거나, 시료 표면에 전자를 가속시켜 주입한다.

\section{2-4. 이차이온질량분석기의 분석 모드}

\section{2-4-1. 표면분석}

표면분석을 통해 알 수 있는 깊이 정보는 고체 시료에 서 방출하는 입자의 탈출 깊이(평균자유행정)에 따라 달 라진다. X선을 시료에 주입할 경우 시료에서 방출하는 입 자의 탈출 깊이가 수십 um이나, 이차이온질량분석기는 
시료에서 이차이온이 탈출하는 깊이를 수십 $\mathrm{nm}$ 이하로 얕게 할 수 있으므로 극표면층 분석이 가능하다. 시료에 주입하는 일차이온의 에너지와 전류밀도를 줄이면 이차 이온은 분자 이온 형태로 방출하며, 스퍼터링 속도가 느 려지므로 얇은 층의 분석이 가능하다.

표면분석은 분석 시 고진공 상태를 유지해야한다. 챔버 에 존재하는 잔류가스에 의해 시료 표면이 오염되거나, 일차이온 및 이차이온의 비행 경로가 왜곡되는 경우가 발 생할 수 있기 때문이다. 특히 얇은 표면층을 분석할 경우 흡착 오염층의 영향이 심각하므로 반드시 초고진공 상태 를 조성해야 한다.

\section{2-4-2. 깊이 방향 분석 $[19,20]$}

일차이온을 시료에 연속적으로 주입하면 시료 표면에 식 각이 일어나 크레이터(crater)가 생긴다. 분석이 끝난 후 크 레이터를 표면단차측정기로 측정하면 일차이온에 의해 식 각이 일어난 깊이를 알 수 있다. 크레이터의 깊이 값과 식 각이 일어날 때 검출한 이차이온 신호를 동기화하면 깊이 에 따른 이차이온 강도(intensity)를 얻을 수 있다. 표준시 료를 활용하면 이차이온의 강도를 농도(concentration)로 변환할 수 있다. 깊이 방향 분석을 통해 수십 $\mathrm{nm}$ 의 얇은 박 막부터 수십 um의 두꺼운 박막, 다층 박막 내 깊이에 따른 미량원소의 농도 분포를 알 수 있다. 반도체 분야의 $90 \%$ 이 상 논문이 깊이 방향 분석에 집중되어 있다. 반도체를 포함 하여 철강, 금속, 세라믹 시료 내 미량 원소의 깊이 방향 분 석이 활발히 이루어지고 있다.

\section{2-4-3. 동위원소 분석}

이차이온질량분석기는 물질 구성 원소의 핵종 종류와 농도를 분석할 수 있어 원리적으로 주성분원소에 대해서 수 \% 또는 그 이하의 정밀도로 동위원소 비를 측정할 수 있다. 그러나 시료 내 동위원소의 비율과 검출한 이차이 온의 강도비(intensity ratio)가 항상 같은 것은 아니다. 분석 과정에서 스퍼터링, 이온화 효율, 이차이온의 비행, 이차이온의 투과율, 검출기의 성능 등에서 따라 동위원소 분별(mass fractionation)이 일어나기 때문이다. 동위 원소를 분석할 때는 측정 정밀도를 높이기 위해 분석 조
건을 세밀하게 설정하여 동위원소 분별 정도 확인, 검출 기의 불감 시간 점검, 표준 시료에서 검증 등이 반드시 필 요하다. 동위 원소 분석 사례는 지구과학분야에서 운석 및 광물내 안정 동위원소 분석을 통한 연대 추정, 생물 분 야에서 생체 시료 내 동위원소 표지(isotope labeling) 분 석을 통한 생명 반응 현상, 신약 개발 등이 있다.

\section{2-5. 이차이온질량분석기 활용 연구 사례 및 분석법 동향}

\section{2-5-1. 고체 산화물 연료 전지용 나노 소재 연구[21]}

나노소재를 고체 산화물 연료전지(solid oxide fuel cells, SOFC)의 전극 물질로 응용하려는 연구가 활발하다. 그러나 일반적인 $\mathrm{SOFC}$ 의 작동온도는 $1173 \mathrm{~K}$ 보다 높기 때문에 나노소재를 적용할 경우 소결, 응집, 반응에 의해 구조 분해가 빨리 일어나는 문제점이 있다.

이를 해결하고자 중온 온도에서 구조가 안정적으로 유 지되는 이중-원주형(double columnar) 구조의 나노 복 합체를 펄스 레이저 증착 (Pulsed Laser Deposition) 방 법으로 제작하였다. 나노 복합체의 음극 활동성을 향상시 키고자 산소 분압이 높은 분위기에서 사마륨을 도핑한 산 화세륨(Sm doped $\left.\mathrm{CeO}_{2}, \mathrm{SDC}\right)$-산화세륨스트론튬코발 트 $\left(\mathrm{Sm}_{0.6} \mathrm{Sr}_{0.4} \mathrm{CoO}_{3}, \mathrm{SSC}\right)$ 나노 복합체를 제작하였다. 그 림 10 과 같이 단일 SDC 박막, 단일 SSC 박막, 이중-원

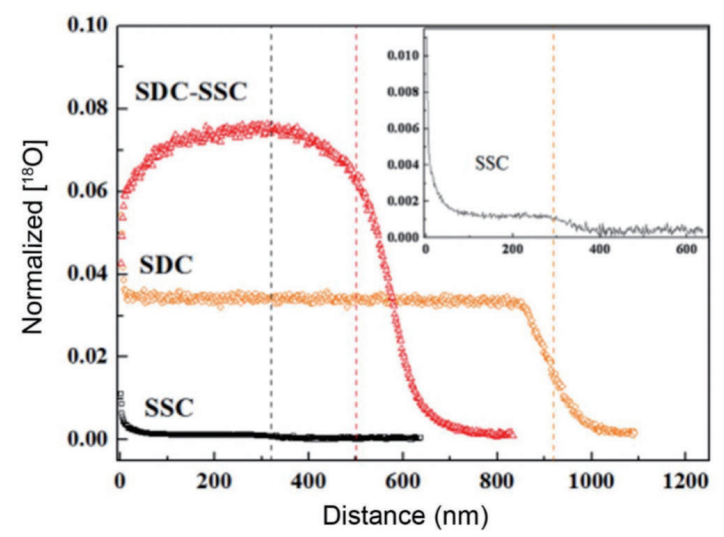

그림 10. SSC 박막, SDC 박막, 이중-원주형 나노 복합체 SDC-SSC 박막 내 ${ }^{18} \mathrm{O}_{2}$ 이온의 $\mathrm{SIMS}$ 분석 결과리 
주형 SDC-SSC 박막 내부 산소 이온의 확산거동을 이차 이온질량분석기로 관찰하였다. 3 종의 박막 내부에 존재 하는 ${ }^{18} \mathrm{O}_{2}$ 이온의 깊이방향 분포 분석 결과, SDC-SSC박 막의 산소 농도가 $\mathrm{SDC}, \mathrm{SSC}$ 단일 박막보다 최소 2 배에 서 최대 70배 이상 높게 나타났으며, 이는 이중-원주형 구조에서 산소 확산이 매우 효과적으로 일어난 것을 알 수 있다. 이중-원주형 SDC-SSC 나노 복합체 박막의 표 면에서 ${ }^{18} \mathrm{O}_{2}$ 이온이 감소하였다가 증가하는 현상은 박막 의 표면에서 내부로 산소 확산이 빠르게 일어난 것으로 추측된다. 나노 수준에서 전극이나 인터페이스의 구조를 제어함으로써 산소 확산 농도가 증가 및 높은 전력 밀도 확보, 구조적 안정성을 달성하였다. 그 결과, 이중-원중 형 나노 복합체를 모바일 애플리케이션과 같은 $\mathrm{SOFC}$ 를 위한 새로운 응용 영역의 미래로 응용 분야를 확장할 수 있을 것이라 예측된다.

\section{2-5-2. 전자세라믹스용 세라믹 박막 연구[22]}

일반적으로 세라믹 재료에서 이동성 이온 종이 결정립 계를 따라 이송될 경우 이동 속도가 빠르고 활성화 에너
지가 낮다고 알려져 있다. 이는 결정립계의 중심부에서 기공의 농도가 높기 때문이다.

그러나 결정립계는 에너지 장벽을 높게 하며, 공간 충 전층 및 결정성 붕괴를 일으키는 단점이 있다고 알려져 있으나 실질적으로 결정립계에 대한 연구가 이루어지지 않았다.

이를 규명하고자 산소 펌프, 고체 산화 전해기 및 고체 산화 연료 전지 등에 활용하는 이트리아 안정화 지르코니 아(yttria-stabilized zirconia, 이하 YSZ)의 결정립계 내 산소 이온의 거동 및 역할에 대해 살펴보았다.

기존의 표면분석방법으로는 수십 나노미터 크기의 직 경을 가진 $\mathrm{YSZ}$ 결정립계와 산소 이온이 어떠한 반응이 일어나는지 알 수 없었으나, $50 \mathrm{~nm}$ 크기의 높은 수준의 공간분해능을 구현할 수 있는 초미세 이차이온질량분석 기(CAMECA, NanoSIMS-50L)를 이용하여 YSZ 결정 립계 내 산소동위원소비 및 분포를 관찰하였다. 그림 11 과 같이 $-0.5 \mathrm{~V}, 600$ 도 분위기에서 ${ }^{18} \mathrm{O}_{2}$ 산소 가스를 주 입한 YSZ와 산소 가스를 주입하지 않은 $\mathrm{YSZ}$ 의 결정립계 내 산소 동위원소 이미지 분석을 통해 결정립계에서 산소 (a)

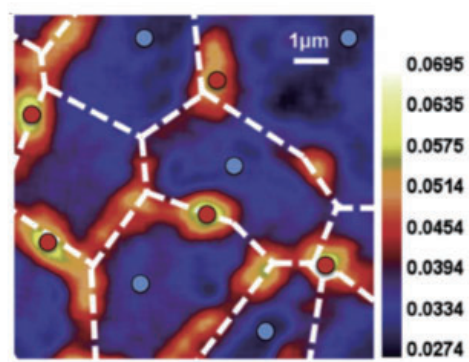

(c)

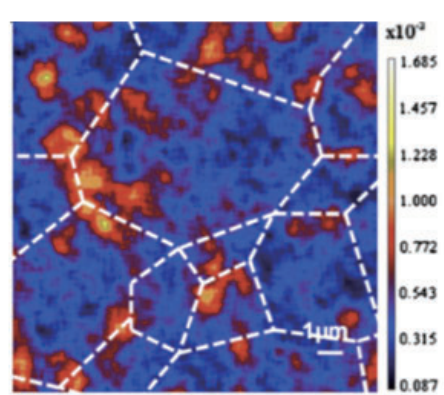

(b)

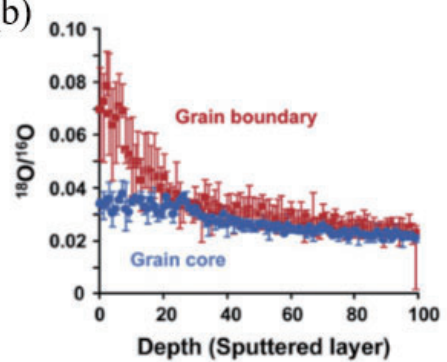

(d)

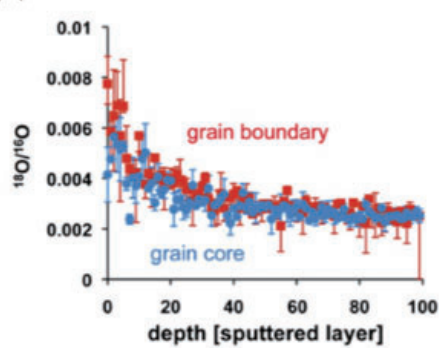

그림 11. ORP (oxygen reduction reaction) 공정 이후 NanoSIMS 분석 결과 (a) YSZ 표면의 ${ }^{18} \mathrm{O} /{ }^{16} \mathrm{O}$ 농도비 이미지 분포 분석 결과 (b) ${ }^{18} \mathrm{O} /{ }^{16} \mathrm{O}$ 농도비 깊이 방향 분포 분석 결과, ORP (oxygen reduction reaction) 공정 이전 NanoSIMS 분석 결과 (c) YSZ 표면의 ${ }^{18} \mathrm{O} /{ }^{16} \mathrm{O}$ 농도비 이미지 분포 분석 결과 (d) ${ }^{18} \mathrm{O} / 16 \mathrm{O}$ 농도비 깊이 방향 분포 분석 결과 22$]$ 
(a)

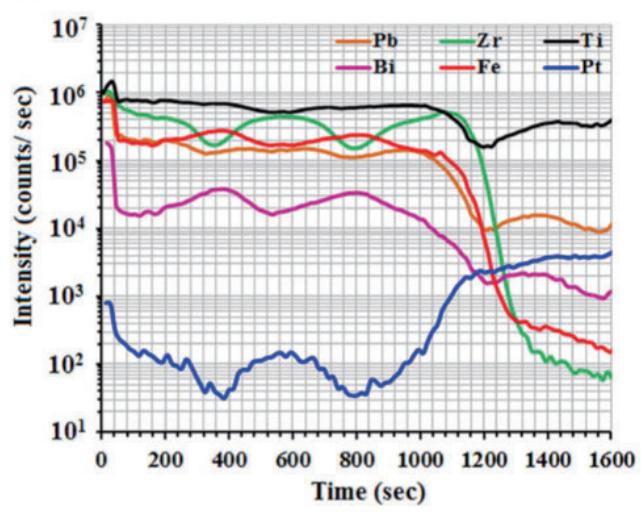

(b)

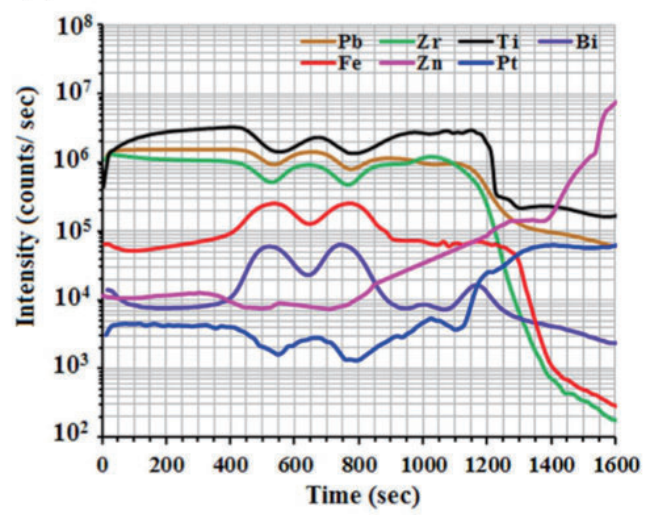

그림 12. PZT-BFO 다층박막의 원소별 깊이방향 분포 SIMS 분석 결과 (a) ZnO buffer layer가 없는 PZT-BFO 다층박막 (b) ZnO buffer layer 를 증착한 PZT-BFO 다층박막[23]

반응이 활성화되었음을 확인하였다. 결정립계가 이온 전 도 측면에서는 높은 저항을 값을 가지나, 산소 이온과의 반응성은 결정면보다 높게 나타났다. 이러한 결과는 더 작은 결정립계(즉, 높은 결정립계 밀도)가 더 낮은 전극 임피던스를 나타낸다. 저온에서 작동하는 고체 산화물 연 료 전지의 경우 전기화학적 성능을 향상시키기 위해 나노 구조 YSZ의 결정립계 밀도 조절이 가능하다는 것을 제시 하였다.

\section{2-5-3. 전자소자용 다강체 물질 연구[23]}

비스무트 페라이트 $\left(\mathrm{BiFeO}_{3}\right.$, 이하 $\left.\mathrm{BFO}\right)$ 는 상온에서 강 유전성과 반자성을 동시에 갖는 장점을 가져 압전소자, 전 자소자 물질로 각광받고 있으나 낮은 유전율, 높은 누설 전류 밀도로 인해 응용분야가 제한적이다. 이러한 한계를 극복하기 위해 두가지 이상의 다강체 물질을 혼합하거나 치환하는 연구가 활발히 진행 중이다. 그 예로 티탄산지르 콘납 $\left(\mathrm{Pb}(\mathrm{Zr}, \mathrm{Ti}) \mathrm{O}_{3}\right.$, 이하 $\left.\mathrm{PZT}\right)$ 과 $\mathrm{BFO}$ 를 혼합한 $\mathrm{PZT}-$ $\mathrm{BFO}$ 다층박막을 제조하여 분극 특성과 강유전율을 개선 하고자 한다. 기판사이의 격자 부정합을 최소화하고자 기 판과 $\mathrm{PZT}-\mathrm{BFO}$ 박막 사이에 $\mathrm{ZnO}$ buffer layer 증착 후 후열처리(650도) 공정에 따른 다강체 박막의 특성을 관찰 하였다. 그림 12 과 같이 이차이온질량분석기(CAMECA, ims-7f)를 통해 ZnO buffer layer의 형성 여부 및 $\mathrm{PZT}$
박막 내부의 확산 여부를 발견하였으며, 열처리후 $\mathrm{PZT/}$ $\mathrm{BFO} / \mathrm{PZT}$ 다층 박막의 계면이 뚜렷이 구별되는 것을 확 인할 수 있다. 이차이온질량분석기를 비롯한 PL, Raman 을 이용하여 $\mathrm{PZT}-\mathrm{BFO}$ 박막의 물성 및 광학 특성 규명을 통해 다강체 물질의 응용 분야를 넓히고자 한다.

\section{3. 결론}

이차이온질량분석기를 이용한 재료 물성 연구는 반도체 산업의 발전과 함께 빠르게 발전하여 왔으며, 국내 메모리 반도체산업이 세계를 석권하는데 크게 기여하고 있다. 이 차이온질량분석기를 활용한 미량 도펀트 분포 평가 기술 이 확립되어 수 $\mathrm{nm}$ 급 트랜지스터 구현이 가능해졌다.

그러나 국내에서는 이차이온질량분석기의 연구분야가 반도체 분야에 국한되어 매우 아쉬운 상황이다. 해외에서 는 이차이온질량분석기의 초정밀 분석기술을 활용하여, 세라믹소재, 생체 소재, 신약개발 및 지질학 등과 같은 다 양한 분야에서 활발한 연구를 수행하여 우수한 연구성과 들이 보고되고 있으나, 우리나라에서는 아직도 이러한 분 야에서 공동연구가 부족한 것이 현실이다.

향후, 세라믹소재의 불순물 제어를 통한 특성 개선 연 구는 이차이온질량분석기의 좋은 연구 분야가 될 것으로 기대한다. 이차이온질량분석기의 이미지 분석법으로 시 


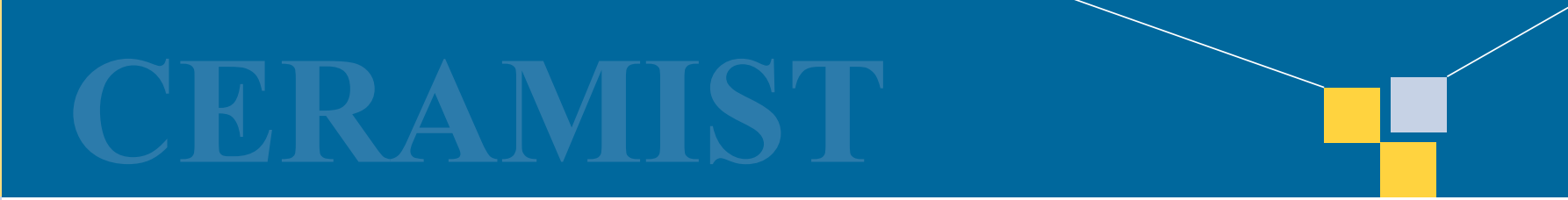

특 집 ㅁㅃ변미랑, 김다영, 홍태은

(a)

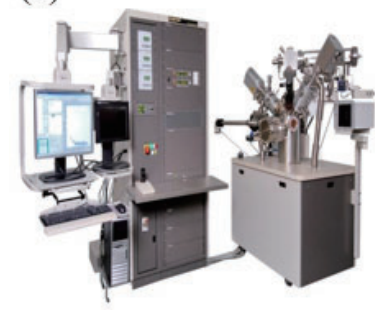

(d)

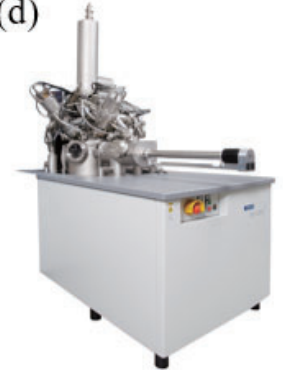

(b)

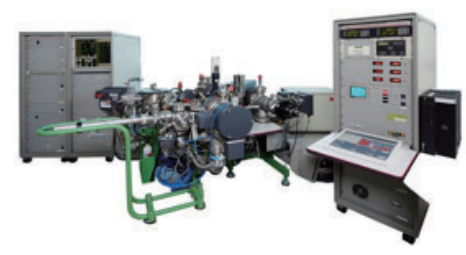

(e)

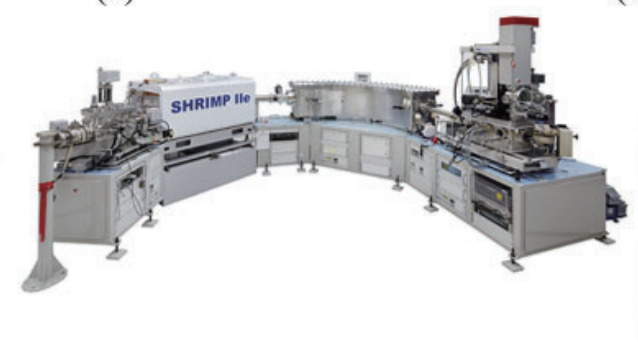

(c)

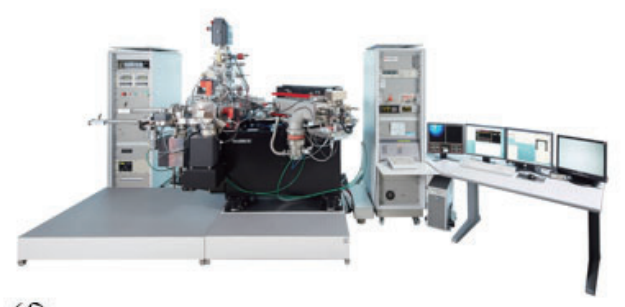

(f)

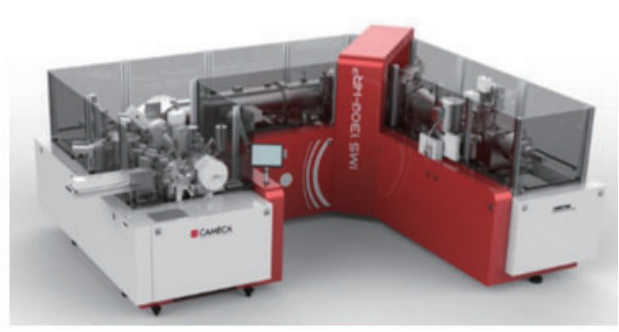

그림 13. 한국기초과학지원연구원에 설치 및 운영 중인 이차이온질량분석기 (A) 사중극자형 이차이온질량분석기 (PHI, ADEPT-1010), (b) 자 기 섹터형 이차이온질량분석기 (CAMECA, ims-6f), (c) 초미세 이차이온질량분석기 (CAMECA, NanoSIMS ${ }^{50)}$, (d) 비행시간형 이차 이온질량분석기 (ION-TOF, TOF-SIMS), (e) 고분해능 이차이온질량분석기 (ASI, SHRIMP IIe/MC) (f) 동위원소현미경 (CAMECA, $1300-\mathrm{HR}^{3)}$

료 표면 및 계면 내 불순물의 확산 · 치환 분포를 관찰하 거나 정량화 한다면 많은 성과를 도출할 수 있을 것이다. 그림 13 과 같이 현재 한국기초과학지원연구원에 설치 된 이차이온질량분석기가 다양한 연구분야의 원천기술 개발과 연구 경쟁력 향상에 폭 넓게 기여할 수 있기를 바 란다.

\section{참고문헌}

1. A. Benninghoven, F.G.Rudenauer, and H.W.Werner, Secondary Ion Mass Spectrometry: Basic Concepts, Instrumental Aspects, Applications, and Trends, Wiley, New York (1987)

2. R.G. Wilson, F.A.Stevie, and C.W.Magee, Secondary Ion Mass Spectrometry: A Practical Handbook For Depth Profiling And Bulk Impurity Analysis, Wiley (1989)

3. John C. Vickerman, Alan Brown, and Nicola M. Reed. "Secondary ion mass spectrometry: principles and applications", Oxford Science Publications (1989)

4. Vickerman, J.C. and Winograd, N., "SIMS-A precursor and partner to contemporary mass spectrometry" Int. J. Mass Spectrom., 377, [1], 568579 (2015)

5. Liebl, H. and Herzog, R.F.K., "Sputtering ion source for solids", Journal of Applied Physics, 34, [9], 28932896 (1963)

6. J.A.McHugh, and A.W.Czanderna, "Methods of Surface Analysis", Oxford (1975)

7. Fred A. Stevie, "Secondary ion mass spectrometry: Applications for Depth Profiling and Surface Characterization", Momentum Press (2016)

8. PaulvanderHeide, "Secondary IonMassSpectrometry", Willy (2014)

9. Alton, G.D., "Characterization of a cesium surface ionization source with a porous tungsten ionizer. I.", Rev. Scientific Instr, 59, [7] 1039-1044 (1988)

10. Coath, C.D., Long, J.V.P., "A high-brigtness duoplasmatron ion source for microprobe secondaryion mass spectrometry", Rev. Scientific Instr, 66, [2], 1018-1023 (1995)

11. Mahoney, C.M., "Cluster Secondary Ion Mass Spectrometry: Principles and Applications", Wiley (2013)

12. Mair, G.L.R., "Liquid metal ion sources and their applications". International Journal of Mass Spectrometry and Ion Physics, 114, [1], 1-21 (1992)

13. 최변각, "이차이온질량분석기의 구조와 원리", 한국기초 
과학지원연구원 (2019)

14. Dawson, P.H. "Quadrupoles for secondary ion mass spectrometry", International Journal of Mass Spectrometry and Ion Physics, 17, [4] 447-467 (1975)

15. J. C. Vickerman, David Briggs, "TOF-SIMS: Materials Analysis by Mass Spectrometry", IM Publications LLP (2013)

16. Neetu, K. and Bihani, S.G.L., "A review on mass spectrometry detectors". International Research Journal of Pharmacy, 3, [10], 33-42 (2012)

17. Wittmaack, K., "Primary-ion charge compensation in SIMS analysis of insulators", J. Appl. Phys., 50, [1] 493-497 (1979)

18. Migeon, H.N., Schuhmacher, M., Slodizan, G., "Analysis of insulating specimens with the Cameca IMS4f", Surf. Interface Anal. 16, 9-13 (1990)

19. P D.Briggs, and M.P.Seah, "Practical Surface Analysis", Wiley (1992)
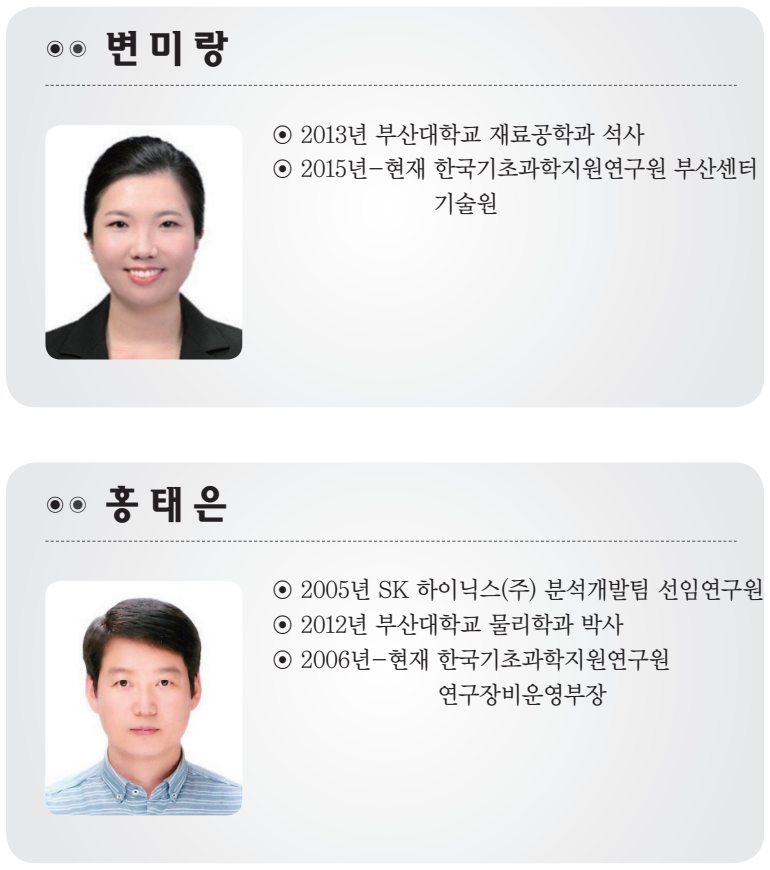

20. McPhail, D. S. "Applications of secondary ion mass spectrometry (SIMS) in materials science”, J. Mater. Sci., 41, [3], 873-903 (2006)

21. Tatsumi Ishihara, "Nanomaterials for Advanced Electrode of Low Temperature Solid Oxide Fuel Cells (SOFCs)", J. Kor. Ceram. Soc., 53 [5] 469-477 (2016) 22. Joon Hyung Shim, Joong Sun Park, Timothy P. Holme, Kevin Crabb, Wonyoung Lee, Young Beom Kim, XuTian, TurgutM. Gür, FritzB. Prinz,"Enhanced Oxygen exchange and incorporation at surface grain boundaries on an oxide ion conductor", Acta Mater., 60 [1] 1-7 (2012)

23. Shankar Dutta, Akhilesh Pandey, Kajal Jindal, O. P. Thakur, Vinay Gupta, Ratnamala Chatterjee, "Optical properties of $\mathrm{Pb}\left(\mathrm{Zr}_{0.52} \mathrm{Ti}_{0.48}\right) \mathrm{O}$ ${ }_{3} / \mathrm{BiFeO}_{3}$ multilayers with $\mathrm{ZnO}$ buffer layer", Appl. Phys. A, 210 [1] 53-58 (2015)

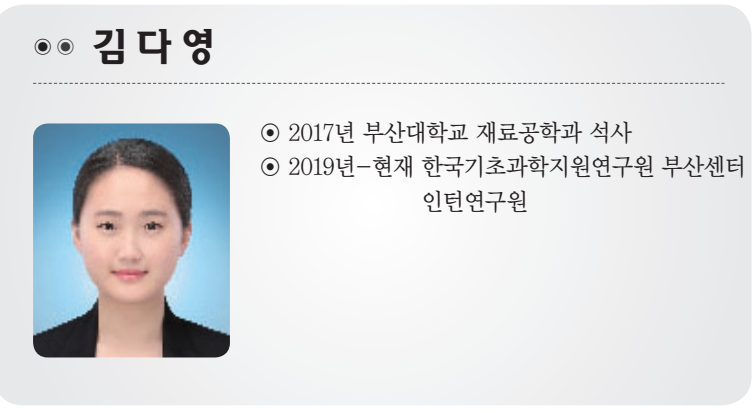

